\title{
Whatsapp Grup Sebagai Media Komunikasi Kuliah Online
}

\author{
Reny Nabilla ${ }^{1}$, Tina Kartika ${ }^{2}$ \\ Program Studi Magister Ilmu Komunikasi, Universitas Lampung, Kota Bandar Lampung, \\ Indonesia \\ Email: renynabil@gmail.com; tina.kartika@ fisip.unila.ac.id
}

\begin{abstract}
In the midst of the Corona or Covid-19 Virus that hit Indonesia, the government issued a policy to temporarily shift the method of face-to-face learning in higher education to the implementation of online-based classes. Like the University of Lampung, the University of Lampung has an online lecture system. In this online lecture process the Whatsapp group feature is one of the media used in this online lecture process. The purpose of this study is to find out how the process and use of Whatsapp as a communication medium for online lectures at the Masters of Communication Sciences University of Lampung class of 2019. The method used in this research is descriptive qualitative method. In collecting this research data, observing whatsapp group. While the research data analysis technique is descriptive qualitative. The results of this study are the features of whatsaap grup is a good alternative used in the online learning process. Lots of benefits arise and also students become active in class even though not doing face to face.
\end{abstract}

Keywords: Whatsapp Group, Benefits, Covid

\begin{abstract}
ABSTRAK
Ditengah Pandemi Virus Corona atau Covid-19 yang melanda indonesia membuat pemerintah mengeluarkan kebijakan untuk sementara mengalihkan metode belajar tatap muka di perguruan tinggi menjadi penerapan kelas berbasis online. Seperti halnya Universitas Lampung, Universitas Lampung memberlakukan sistem kuliah online. Dalam proses kuliah online ini fitur Whatsapp grup merupakan salah satu media yang digunakan dalam proses kuliah daring ini. Tujuan penelitian ini yaitu untuk mengetahui bagaimana proses dan pemanfaatan Whatsapp sebagai media komunikasi kuliah online Magister Ilmu Komunikasi Universitas Lampung angkatan 2019. Metode yang digunakan dalam penelitian ini adalah metode kualitatif deskriptif. Dalam pengumpulan data penelitian ini melakukan observasi terhadap grup whatsapp. Sedangkan teknik analisis data penelitian ini yaitu deskriptif kualitatif. Hasil penelitian ini adalah fitur whatsaap grup merupakan salah satu alternative yang baik digunakan dalam proses pembelajaran online. Banyak sekali manfaat yang ditimbulkan dan juga mahasiswa menjadi aktif dalam kelas walaupun tidak melakukan tatap muka.
\end{abstract}

Kata kunci : Whatsapp Grup, Manfaat, Covid 


\section{Pendahuluan}

Saat ini dunia digemparkan dengan kehadiran virus baru yang bernama Covid19 atau virus corona. Virus ini sekarang telah menyebar ke 190 negara didunia termasuk di Indonesia. Dengan meluasnya virus corona ini di Indonesia berdampak pada terganggunya aktivitas masyarakat. Salah satunya adalah kegiatan belajar mengajar di setiap sekolah dan universitas. Pemerintah membuat peraturan bahwa sekolah dan universitas belajar dirumah hal itu dilakukan guna mengurangi penyebaran virus corona ini.

Salah satu upaya yang dilakukan oleh sekolah dan universitas dalam hal ini yaitu memberlakukan kuliah online kepada para siswa dan mahasiswanya dengan memanfaatkan teknologi informasi. (Adijaya \& Santosa, 2018) Pembelajaran online atau pembelajaran virtual dianggap sebagai paradigma baru dalam proses pembelajarn karena dapat dilakukan cara yang sangat mudah tanpa harus bertatap muka di suatu ruang kelas dan hanya mengandalkan sebuah aplikasi berbasis koneksi internet maka proses pemebelajaran dapat berlangsung.

Penggunaan teknologi informasi seperti halnya penggunaan internet ini yang telah memiliki berbagai aplikasi seperti media sosial, merupakan salah satu media dimana para penggunanya dapat saling berkomunikasi, mencari informasi dan menjalin pertemanan. Seperti diketahui ragam media sosial yakni adalah facebook, twitter, line, bbm, whatsapp, instagram, path, ask.fm, linkedin, snapchat dan beberapa media sosial yang lain. Menurut (Carr \& Hayes, 2015) Media sosial adalah media berbasis Internet yang memungkinkan pengguna berkesempatan untuk berinteraksi dan mempresentasikan diri, baik secara seketika ataupun tertunda, dengan khalayak luas maupun tidak yang mendorong nilai dari user-generated content dan persepsi interaksi dengan orang lain. Dalam hal ini akan membuat individu mudah untuk berkomunikasi dan berkomentar tentang berbagai kasus maupun topik yang dibahas oleh individu lain. Dengan ini juga dapat membangun opini, emosi dan kepercayaan melalui komentar, sudut pandang maupun pemikiran individu lain dalam media social. Seperti halnya dalam penggunaan dari aplikasi whatsapp.

(Suryadi et al., 2018) Keberadaan media sosial WhatsApp merupakan salah satu bukti perkembangan teknologi dan komunikasi yang harus disikapi dengan positif. Aplikasi WhatsApp menjadi aplikasi yang paling diminati kedua, yang digunakan oleh berbagai macam kelompok masyarakat di Indonesia, tak terkecuali oleh para akademisi perguruan tinggi seperti mahasiswa dan dosen di Univeristas Lampung. Aplikasi WhatsApp khususnya 
fitur WhatasApp Grup dirasa ideal digunakan sebagai sarana diskusi mahasiswa dan penyebaran informasi akademik di lingkungan universitas lampung sebagai upaya yang dilakukan oleh pihak kampus agar keberlangsungan kuliah para mahasiswa atau mahasiswinya tetap berjalan efektif ditengah pendemi virus corona ini. Hal ini dikarenakan karena Grup WA memiliki manfaat pedagogis, sosial, dan teknologi. Aplikasi ini memberikan dukungan dalam pelaksanaan pembelajaran secara online (Pratama, 2019).

Pemanfaatan WhatsApp Grup di lingkungan universitas Lampung ini sangat tinggi, tak terkecuali di Fakultas Ilmu sosial dan ilmu poitik jurusan Magister Ilmu Komunikasi. Hampir semua dosen dari magister ilmu komunikasi menggunakan whatsapp grup sebagai alat komunikasi mereka dalam penerapan kuliah online ini. Para mahasiswa diharapkan masuk dan terlibat selama proses perkuliahan berlangsung. Penggunaan whatsapp grup ini dilakukan oleh pihak kampus guna sebagai media komunikasi untuk mahasiswa dan dosen agar perkuliahan tetap efektif walaupun tidak tatap muka langsung.

Whatsapp merupakan salah satu media sosial yang saat ini banyak digunakan sebagai penyampaian pesan baik oleh individu maupun kelompok maupun untuk kepentingan bersosialisasi. (Aminoto \& Dani, 2018) Keberadaan WhatsApp Messenger tidak terlepas dari generasi digital yang selalu menginginkan adanya pemutakhiran terhadap berbagai teknologi berbasis internet. Namun sejauh mana penggunaan Whatsapp oleh penggunanya maka dari latar belakang tersebut diatas maka rumusan masalah penelitian ini yaitu bagaimana proses dan pemanfaatan Whatsapp sebagai media komunikasi kuliah online Magister Ilmu Komunikasi Universitas Lampung angkatan 2019?. Sedangkan tujuan penelitian ini untuk mengetahui bagaimana proses dan pemanfaatan Whatsapp sebagai media komunikasi kuliah online Magister Ilmu Komunikasi Universitas Lampung angkatan 2019.

\section{Metode Penelitian}

Metode penelitian yang digunakan adalah kualitatif, yang bermaksud untuk mendeskripsikan dan menganalisa fenomena, peristiwa, aktivitas, sikap, persepsi, dan pemikiran orang secara individual atau kelompok, serta untuk memahami fenomena apa yang dialami subjek penelitian, baik perilaku, persepsi, motivasi, tindakan, dan lain-lain secara holistik (Sugiyono, 2012).

Penelitian ini menggunakan teknik pengumpulan datanya yaitu observasi melalui pengamatan terhadap aktivitas chat 
di dalam Grup WA serta dokumentasi. Selanjutnya, teknik analisis data yang dilakukan adalah deskriptif kulitatif. Analisis deskriptif yang dimaksud dalam penelitian ini adalah untuk memberikan informasi mengenai data yang diamati agar bermakna.

\section{Hasil dan Pembahasan}

Pada bagian ini, peneliti akan memaparkan beberapa hal, diantaranya: 1 . Asalmula kuliah online, 2. Proses pembentukan grup Whatsapp dan proses perkuliahan atau pemberian materi di dalam Grup WA yang telah dibentuk, 3. Hasil perkuliahan online, 4. Pemanfaatan Whatsapp sebagai media komunikasi kuliah online. Adapun analisisnya sebagai berikut: 1. Asal mula Kuliah online

Akhir-akhir ini dunia digegerkan dengan wabah penyakit baru yang saat ini dikenal virus corona atau istilah lainnya covid-19. Covid-19 ini pertama kali muncul di salah satu kota di China yaitu kota Wuhan, awal mulanya virus ini dikarenakan adanya salah satu laboratorium yang pecah di wuhan sehingga muncul virus baru yaitu virus corona. Virus corona ini tidak hanya terjadi di negara China saja tetapi telah menyebar ke belahan negara lainnya, salah satunya yaitu negara Indonesia. Virus corona di Indonesia sejauh ini telah mencapai 5923 kasus positif, 520 pasien meninggal dan juga 607 pasien yang sudah dinyatakan sembuh dari virus corona ini (Hastuti, 2020).

Virus Covid-19 atau corona yang melanda Indonesia, membuat pemerintah mengeluarkan kebijakan untuk mengalihkan metode pembelajaran di perguruan tinggi yang sebelumnya bertatap muka menjadi penerapan kelas berbasis online. Kebijakan pemerintah ini merupakan langkah yang diambil pemerintah untuk kebaikan bersama walaupun memiliki banyak pertimbanganpertimbangan di masyarakat.

Gambar 1. Pemberitaan kuliah online oleh suatu media nasional

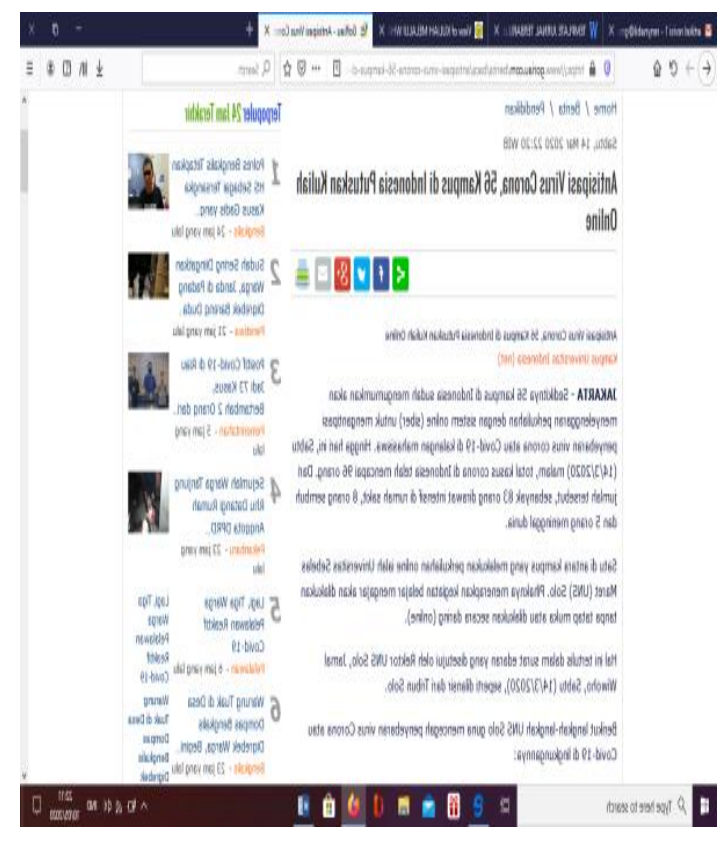

Pada gambar 1 diatas menerangkan bahwa banyak Universitas di Indonesia memberlakukan kuliah online untuk mengantipasi penyebaran virus corona dilingkungan kampus (Ansam, 2020). Dalam menerapkan kuliah online ini banyak Universitas menggunakan aplikasi- 
aplikasi sebagai media komunikasi pengganti kuliah tatap muka. Beberapa aplikasi seperti zoom, whatsaap, google teams dan masih banyak lagi. Salah satu Universitas yang memberlakukan kuliah online yaitu Universitas Lampung.

2. Proses pembentukan grup Whatsapp dan proses perkuliahan atau pemberian materi di dalam Grup WA yang telah dibentuk

Universitas Lampung merupakan salah satu universitas yang memberlakukan sistem kuliah online. Pihak masing-masing jurusan telah melaksanakan kuliah online dengan memanfaatkan berbagai aplikasi. Seperti yang dilakukan oleh jurusan Magister Ilmu Komunikasi Universitas Lampung angkatan 2019 dalam penerapan kuliah online ini dengan menggunakan aplikasi Whatsapp grup. Dengan penggunaan fitur whatsapp grup ini dilakukan agar perkuliahan tetap berjalan efektif walaupun tidak bertatap muka langsung. Pada jurusan Magister Ilmu Komunikasi angkatan Tahun 2019 penerapan kuliah online ini telah berlangsung sejak tanggal 21 Maret 2020 sampai tanggal 2 Mei 2020.
Gambar 2. Grup mata kuliah Media dan

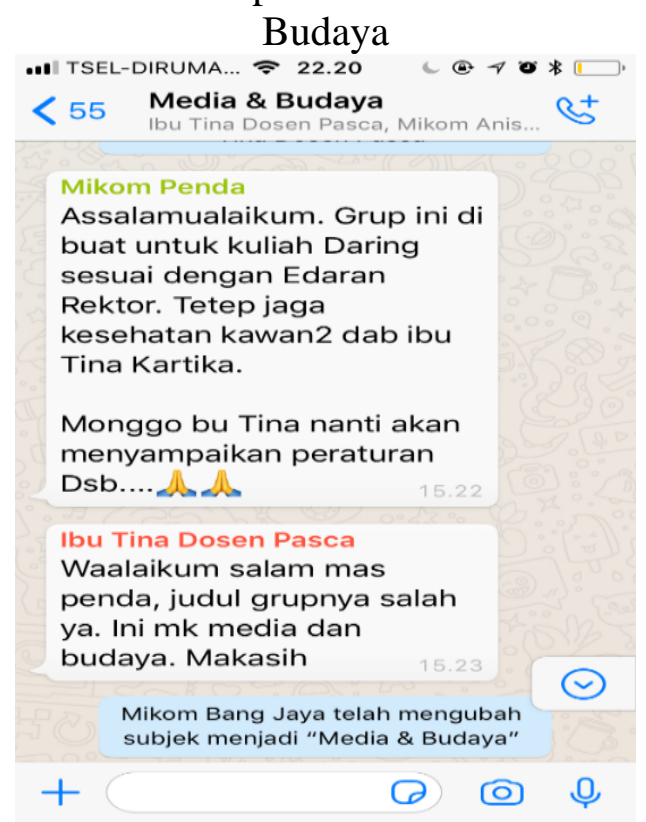

Gambar 2 diatas merupakan salah satu grup yang dibuat untuk proses perkuliahan online. Ketua kelas membuat grup whatsapp, setelah itu mengundang mahasiswa dan dosen dimatakuliah tersebut. Grup WhatsApp dibagi permasing-masing mata kuliah. Semester dua (2) ini angkatan 2019 magister ilmu komunikasi mengambil empat (4) mata kuliah, terdapat empat grup Whatsapp.

Gambar 3. Proses absensi dan pemberian materi

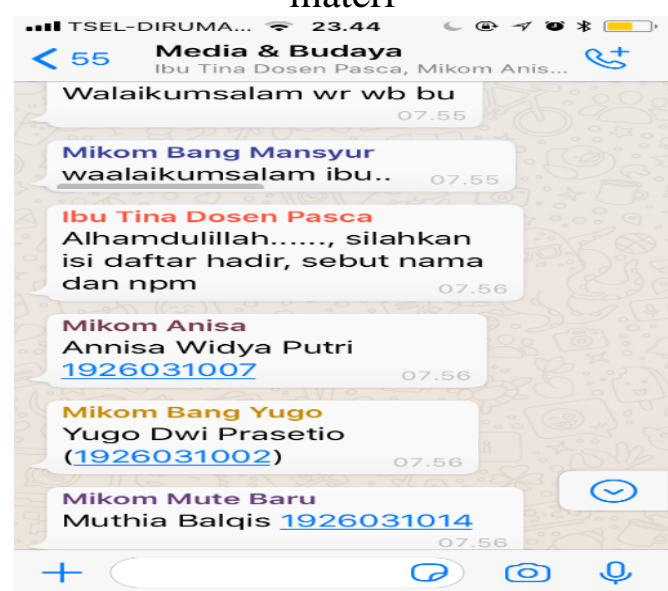




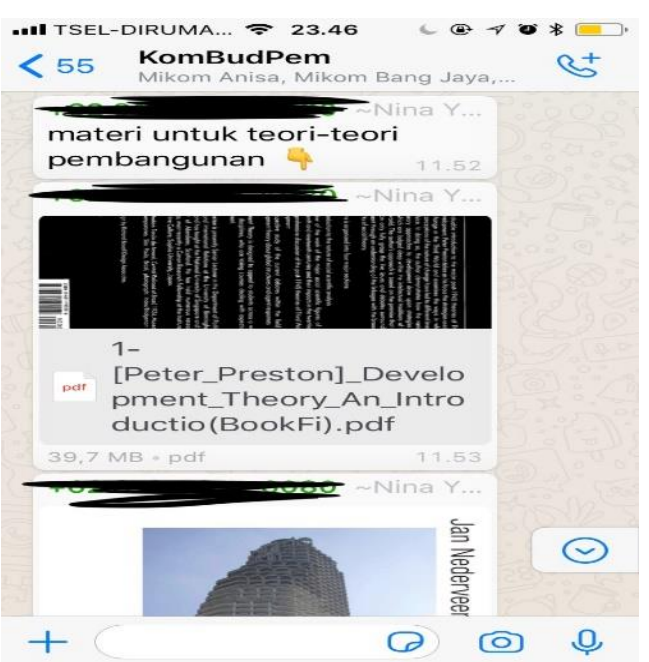

Gambar 3 diatas memperlihatkan proses absensi yang dilakukan di whatsapp grup. Saat jam telah menunjukan waktu dimulai perkuliahan, dosen akan melakukan absensi terlebih dahulu. Setelah semua mahasiswa telah melakukan absen maka setelah itu, dosen akan mengirimkan file materi perkuliahan dan menerangkan materi perkuliahan.

Gambar 4. Tanya jawab

\begin{tabular}{|c|c|}
\hline 54 & $\begin{array}{l}\text { Manaj.Komunikasi MIkom } \\
\text { Mikom Anisa, Mikom Bang Jaya,... }\end{array}$ \\
\hline & $\begin{array}{l}\text { Mikom Bang Yugo } \\
\text { Bu saya mau bertanya, seberapa } \\
\text { penting kah audit komunikasi ini } \\
\text { dalam keorganisasian Bu? }\end{array}$ \\
\hline & $\begin{array}{l}\text { Izin menanggapi. Menurut } \\
\text { saya sangat penting dangan } \\
\text { kita melakukan pengauditan } \\
\text { komunikasi kita jadi tau } \\
\text { apakah program akatu } \\
\text { kegiatan yang kita jalankan } \\
\text { sudah efektif atau belum. } \\
\text { Apabila belum bisa dapat } \\
\text { kita evaluasi. }\end{array}$ \\
\hline \multicolumn{2}{|c|}{$\begin{array}{l}\text { Mikom Mba Ratu } \\
\text { izin bertanya bu, apakah ada } \\
\text { syarat tertentu suatu } \\
\text { organisasi dapat melakukan } \\
\text { audit komunikasi bu? } \\
\text { apakah organisasi yang }\end{array}$} \\
\hline & (0) \\
\hline
\end{tabular}

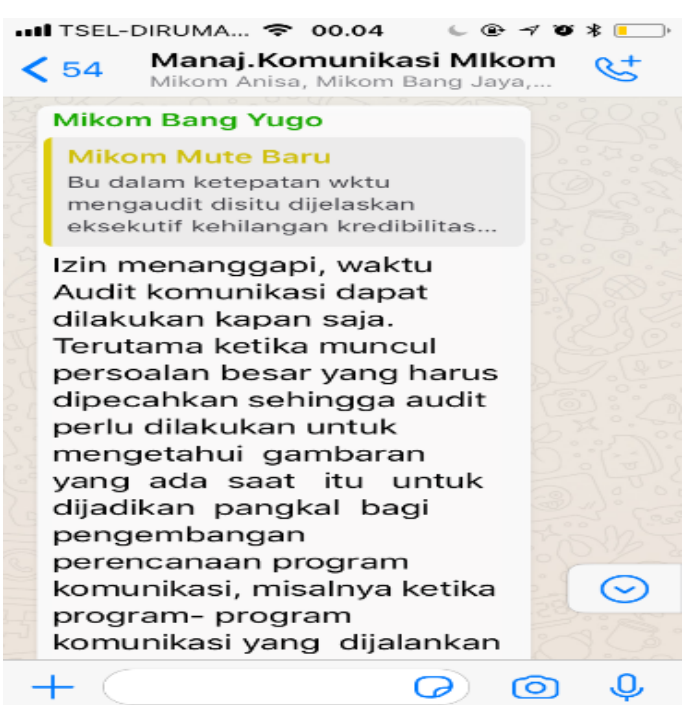

Gambar diatas memperlihatkan bahwa setelah dosen menjelaskan materi maka mahasiswa diberi kesempatan untuk bertanya dan menanggapi dari materi yang diberikan. Mahasiswa dituntut untuk aktif dalam melakukan perkuliahan. Dalam pertemuan mahasiswa wajib mentaati peraturan perkuliahan online yaitu wajib memberikan dua (2) tanggapan. Apabila mahasiswa tidak memberikan tanggapan maka mahasiswa dianggap tidak hadir.

Dalam proses perkuliahan online ini pihak Jurusan Magister Ilmu Komunikasi Universitas Lampung menganut paradigma yang memposisikan mahasiswa sebagai center. Sesi pelajaran meliputi absensi, penyampaian materi pembelajaran, tanya jawab, memberikan tanggapan, dan tugas. Hal ini untuk memastikan bahwa mahasiswa memiliki acuan utama sebagai bahan pembacaan, pemahaman, dan pelaksanaan praktik latihan. Adapun sesi interaktif dimaksudkan agar tercipta iklim dinamik yang kondusif serta membuka 
isolasi agar mahasiswa melakukan kemitraan dan kolaborasi secara terbuka.

3. Hasil perkuliahan online

Sebagai capaian hasil pembelajaran daring, para mahasiswa telah aktif dalam proses pembelajaran. Yang sebelum proses daring ini para mahasiswa banyak yang kurang aktif tetapi dengan diadakan proses pembelajaran daring ini mahasiswa aktif di dalam Whatsapp grup. Mahasiswa mulai berani memberikan pendapat dan juga pertanyaan dari penyampaian materi yang dilakukan oleh masing-masing dosen. Dalam proses pembelajaran online ini juga pencapaian absensi dan waktu kehadiran dari masing-masing mahasiswa juga meningkat. Bila sebelumnya para mahasiswa jarang hadir dan terlambat datang masuk kelas, proses daring ini membuat mahasiswa dapat mengikuti kuliah online tepat waktu. Hal tersebutlah merupakan salah satu hasil dari pemanfaatan penggunanan fitur Whatapp grup.

Mahasiswa dapat berkomunikasi lebih mudah dengan dosen untuk berdiskusi maupun bertanya baik secara umum di grup kelas maupun dengan menghubungi dosen secara pribadi. Diskusi antar mahasiswa pun dapat berjalan dengan baik, dikarenakan mahasiswa dapat dengan bebas memberikan pertanyaan kepada dosen maupun mahasiswa lain didalam grup. (Sukrillah et al., 2018) Diskusi dapat bersumber baik dari suatu informasi yang disengaja untuk memancing diskusi, maupun dari informasi biasa yang ditanggapisecara berkelanjutan sehingga terjadinya suatu proses diskusi. Dengan kesempatan berdiskusi yang sangat luas ini dapat meningkatkan semangat belajar mahasiswa.

Dengan penggunaan fitur ini pula mahasiswa dapat langsung bertanya jika kekurang pahaman dalam topik tertentu, dan dosen juga dapat memberikan pengumuman terbaru melalui whatsapp grup. Pengumuman terbaru ini dapat memberikan notifikasi langsung kepada mahasiwa sehingga mahasiswa dapat langsung mengetahui informasi-informasi terbaru dalam kegiatan perkuliahan.

4. Pemanfaatan Whatsapp sebagai media komunikasi kuliah online

(Grover et al., 2020) WhatsApp dapat membantu mahasiswa berdiskusi dan belajar secara aktif, dan berinteraksi dengan mudah daripada pembelajaran tradisional. WhatsApp secara baik mendukung tujuan pembelajaran di antara aplikasi sosial lainnya. Nilai keterlibatan emosional di whatsaap grup lebih tinggi di platform pesan instan WhatsApp. Dalam penggunaan WhatsApp memberikan dampak positif pada perilaku yang mempengaruhi proses pembelajaran, seperti berbagi pengetahuan, partisipasi di kelas dan persiapan untuk belajar. 
(Darmalaksana et al., 2020) Banyak yang memanfaatkan adanya aplikasi WhatsApp ini untuk mengembangkan model pembelajaran campuran, sementara penggunaan aplikasi lain untuk pengembangan pembelajaran masih sulit ditemui.

Dalam penggunaan fitur WhatsApp grup ini membuktikan bahwa untuk bertukar pikiran dengan sesama mahasiswa juga memerlukan suatu alat sebagai penungjang agar berkomunikasi dapat berjalan secara efektif. (Tina Kartika, 2019) Hakikat komunikasi adalah proses pernyataan antarmanusia yang dinyatakan adalah pikiran atau perasaan seseorang kepada orang lain dengan menggunakann bahasa sebagai alat penyalurnya.

Beberapa dari hasil penelitian ini menunjukkan bahwa penggunaan WhatsApp grup di kelas telah meningkatkan motivasi mahasiswa. Teknik WhatsApp grup diakui dapat menghasilkan efek signifikan pada keterampilan mahasiswa perguruan tinggi, dan ternyata penggunaan mediasi WhatsApp terbukti efektif. Persepsi mahasiswa tentang penggunaan WhatsApp grup dalam pembelajaran menunjukkan bahwa sikap yang positif. Sebagian besar mahasiswa menyukai mobile learning (m-learning) melalui WhatsApp, di mana ada penerimaan metodologi m-learning oleh mahasiswa, dan sikap positif terhadap m- learning di kalangan mahasiswa sangat menjanjikan untuk perubahan paradigma dari e-learning ke m-learning.

(Prajana, 2017) Pembelajaran kolaboratif memiliki kelebihan pada proses pengembangan cara berfikir siswa yang lebih kritis dan rasional, selain itu pembelajaran kolaboratif dapat menumbuhkan kepekaan dalam berkerjasama, bermusyawarah, dan rasa menghargai antar siswa. Model pembelajaran dengan penggunaan papan tulis yang dikombinasikan dengan presentasi power point telah menjadi praktik tradisional di kelas dibandingkan aplikasi yang ada di handphone yang dapat meningkatkan lingkungan dan hasil belajar. (Laode Anhusadar, 2020) Kemajuan pesat teknologi seluler dan ketersediaan ponsel cerdas di setiap mahasiswa telah memberikan ruang lingkup yang luas untuk metodologi m-learning melalui Whatsapp untuk digunakan dalam pendidikan.

Utomo \& Ubaidillah, (2018) Penggunaan teknologi ini dapat memungkinkan terjadinya pergeseran proses pembelajaran yang terbatas pada ruang kelas menjadi lebih luas dan bebas secara ruang dan waktu. Namun, pelaksanaan pembelajaran dengan aplikasi whatsapp grup ini tidak serta merta $100 \%$ efektif, dalam hal ini pola pembelajaran lebih efektif apabila menggabungkan antara tatap muka serta pembelajaran online. 
Pembelajaran era digital dengan menggunakan perangkat teknologi telah banyak memberikan dampak yang positif. Sehingga, paradigma pembelajaran selama ini yang hanya terbatas pada interaksi mahasiswa dengan dosen di ruang kelas saja dapat berkembang menjadi lebih luas, tidak terbatas pada ruang dan waktu. Sebagaimana diketahui, belajar merupakan hasil dari interaksi sosial antara siswa dalam kegiatan pembelajaran kolaboratif. Kegiatan dapat mencakup berbagi melalui perangkat seluler, seperti forum diskusi, yang dapat digunakan untuk berbagi konstruksi pengetahuan. Konstruksi pengetahuan didasarkan pada interaksi sosial antara siswa secara online.

\section{Penutup}

Dalam proses perkuliahan online ini pihak Jurusan Magister Ilmu Komunikasi Universitas Lampung menganut paradigma yang memosisikan mahasiswa sebagai center. Sesi pelajaran meliputi absensi, penyampaian materi perkuliahan, sesi tanya-jawab dan tanggapan, serta tugas. Sebagai capaian hasil pembelajaran online ini, para mahasiswa telah aktif dalam proses pembelajaran. Kesempatan diskusi yang semakin luas dengan optamalisasi penggunaan WA ini meningkatkan semangat belajar mahasiswa. Mahasiswa dapat langsung bertanya jika kurang paham dalam topik tertentu. WhatsApp dapat membantu siswa memperoleh pengetahuan, berdiskusi dan belajar secara aktif, dan berinteraksi dengan mudah daripada pembelajaran tradisional. Penggunaan aplikasi whatsaap grup sebagai sarana kuliah online sangat bermanfaat dan membantu dalam proses berkomunikasi, memberi dan menerima informasi. Penyampaian dan penyebaran berita yang sangat cepat membuat salah satu keunggulan yang diberikan oleh aplikasi whatsapp.

\section{Daftar Pustaka}

Adijaya, N., \& Santosa, L. P. (2018). Persepsi Mahasiswa dalam Pembelajaran Online. Wanastra. https://doi.org/2579-3438

Aminoto, T., \& Dani, R. (2018). Aminoto, T., \& Dani, R. (2018). Pengembangan Model Diskusi Berbasis Whatsapp Untuk Meningkatkan Pemahaman Konsep Pada Mata Kuliah Fisika Statistik. EduFisika. https://doi.org/10.22437/edufisika.v3i 01.5804Pengembangan Model Diskusi Berbasis Whatsapp Untuk . EduFisika.

https://doi.org/10.22437/edufisika.v3i 01.5804

Ansam, H. (2020). Antisipasi Virus Corona, 56 Kampus Di Indonesia Putuskan Kuliah Online. Goriau.Com. https://www.goriau.com/berita/baca/a ntisipasi-virus-corona-56-kampus-diindonesia-putuskan-kuliahonline.html

Carr, C. T., \& Hayes, R. A. (2015). Carr, C. T., \& Hayes, R. A. (2015). Social Media: Defining, Developing, and 
Divining. Atlantic Journal of Communication, 23(1), 46-65. https://doi.org/10.1080/15456870.201 5.972282Social Media: Defining, Developing, and Divining. Atlantic Journal of Communication. https://doi.org/10.1080/15456870.201 5.972282

Darmalaksana, W., Hambali, R. Y. A., Masrur, A., \& Muhlas. (2020). Analisis Pembelajaran Online Masa WFH Pandemic Covid-19 sebagai Tantangan Pemimpin Digital Abad 21. UIN Sunan Gunung Djati Bandung.

Grover, S., Garg, B., \& Sood, N. (2020). Introduction of case-based learning aided by WhatsApp messenger in pathology teaching for medical students. Journal of Postgraduate Medicine.

https://doi.org/10.4103/jpgm.JPGM_2 -19

Hastuti, R. K. (2020). Corona RI 17 April, 5.923 Positif, 520 Meninggal, 607 Sembuh. Cnbcindonesia.Com. https://www.cnbcindonesia.com/news /20200417151135-4-152745/coronari-17-april-5923-positif-520meninggal-607-sembuh

Laode Anhusadar. (2020). PERSEPSI MAHASISWA PIAUD TERHADAP KULIAH ONLINE DI MASA PANDEMI COVID 19. KINDERGARTEN: Journal of Islamic Early Childhood Education. https://doi.org/http://dx.doi.org/10.24 014/kjiece.v3i1.9609

Prajana, A. (2017). PEMANFAATAN APLIKASI WHATSAPP UNTUK MEDIA PEMBELAJARAN DALAM LINGKUNGAN UIN AR-RANIRY BANDA ACEH. Cyberspace: Jurnal Pendidikan Teknologi Informasi. https://doi.org/10.22373/cs.v1i2.1980

Pratama, R. A. (2019). KULIAH MELALUI WHATSAPP
(KULWAPP). De Fermat: Jurnal Pendidikan Matematika. https://doi.org/10.36277/defermat.v2i 1.32

Sugiyono. (2012). Metode Penelitian Kuantitatif, Kualitatif dan R \& D.Bandung:Alfabeta. Metode Penelitian Kuantitatif, Kualitatif Dan $R \quad \& \quad$ D.Bandung:Alfabeta. https://doi.org/10.1017/CBO9781107 415324.004

Sukrillah, A., Ratnamulyani, I. A., \& Kusumadinata, A. A. (2018). Pemanfaatan Media Sosial Melalui Whatsapp Grup Fei Sebagai Sarana Komunikasi. Jurnal Komunikatio. https://doi.org/10.30997/jk.v3i2.919

Suryadi, E., Ginanjar, M. H., \& Priyatna, M. (2018). Penggunaan Sosial Media Whatsapp Pengaruhnya Terhadap Disiplin Belajar Peserta Didik Pada Mata Pelajaran Pendidikan Agama Islam (Studi Kasus Di SMK Analis Kimia YKPI Bogor). Edukasi Islami : Jurnal Pendidikan Islam. https://doi.org/10.30868/ei.v7i01.211

Tina Kartika, T. B. (2019). Komunikasi Antarpribadi Dan Komunikasi Kelompok Tenaga Pengamanan Perambah Hutan Illegal Untuk Mengatasi Perambahan Hutan. LINIMASA: JURNAL ILMU KOMUNIKASI.

https://doi.org/10.23969/linimasa.v2i2 .1689

Utomo, S. W., \& Ubaidillah, M. (2018). Pemanfaatan Aplikasi Whatsapp Pada Pembelajaran Berbasis Masalah Untuk Mata Kuliah Akuntansi Internasional Di Universitas Pgri Madiun. Kwangsan: Jurnal Teknologi Pendidikan. https://doi.org/10.31800/jtp.kw.v6n2. p199--211 